\title{
Hydrological Conditions in the Western Part of the Black Sea in November, 2015 (Based on the Data Obtained in the $81^{\text {st }}$ Cruise of $\mathrm{R} / \mathrm{V}$ Professor Vodyanitsky)
}

\author{
Ju.V. Artamonov, D.V. Alexeev, S.I. Kondratyev, E.A. Skripaleva, \\ S.A. Shutov, V.N. Lobachyov, R.O. Shapovalov, A.V. Fedirko \\ Marine Hydrophysical Institute, Russian Academy of Sciences, Sevastopol, \\ Russian Federation \\ e-mail: sea-ant@yandex.ru
}

\begin{abstract}
The results of the hydrological research carried out in November, 2015 nearby the Crimea coast and in the northwestern part of the Black Sea Western cyclonic gyre are presented. It is shown that the Rim Current is represented by its coastal branch over the continental slope and its southern branch located over the central part of the basic polygon. The south-eastern undersurface countercurrent is observed over the coastal shelf. In the southeastern part of the basic polygon the cyclonic meander was discovered. Within the whole research area the sea surface temperature exceeds the climate norm. High positive anomalies of actual temperature are observed nearby the Crimea coast in the area of maximum interannual variations and in the southern part of the research area where synoptic variability increases and the interannual one - decreases. Positive temperature anomalies in the cold intermediate layer core in November, 2015 (relative to the climate norm) are in good agreement with general tendency of sea surface temperature growth on the multi-year scale. Anomalously warm winters in the research area in the recent years have contributed to the cold intermediate layer thermal content increase. The salinity during the survey on the most of the research area was above normal. Only on the shelf, unlike the temperature, the weak negative salinity anomalies were observed. The highest positive salinity anomalies were monitored in the eastern part of the polygon.
\end{abstract}

Keywords: the Black Sea, thermohaline fields, the Rim Current, cold intermediate layer, Western cyclonic gyre, Chersonesos-Bosporus section, spatial-temporal variability.

DOI: 10.22449/1573-160X-2016-4-57-70

(C) 2016, Ju.V. Artamonov, D.V. Alexeev, S.I. Kondratyev, E.A. Skripaleva, S.A. Shutov, V.N. Lobachyov, R.O. Shapovalov, A.V. Fedirko

(C) 2016, Physical Oceanography

Introduction. The research in the $81^{\text {st }}$ cruise of $\mathrm{R} / \mathrm{V}$ Professor Vodyanitsky was carried out within the framework of the projects: "Fundamental oceanography" and "Climate" of Marine Hydrophysical Institute (MHI, Sevastopol) and the program of P.P. Shirshov Institute of Oceanology (IO, Moscow) under the Contract No. 07-09 dated September 7, 2015 between IO and MHI. The principal purpose of the expedition was to study the biogeochemical, optical and sedimentation processes in the Black Sea. The oceanographic studies were aimed to assess the hydrological conditions the particular features of the seawater biogeochemical and optical characteristics were formed against.

The research was carried out on November $3-10,2015$ on ChersonesosBosporus section in the northwestern part of the Black Sea Western cyclonic gyre (WCG). The research area has the hydrologic features found in seasonal and interannual variability of the temperature, salinity and geostrophic speed fields [1 6]. The seasonal variability maximum of the Rim Current zonal velocity is marked on the basis of contact and satellite measurements. The seasonal variability minimum of the sea surface temperature (SST) is observed southward of the Crimean Peninsula. Nearby the Crimea coast during the period of the highest Rim Current intensification in late winter - early spring the "tongue" of the warm waters coming from the eastern Black Sea is clearly seen. It smoothes the intraannual temperature contrasts $[3,4]$. To the east of $33^{\circ} \mathrm{E}$ along the coast of the Crimea amplitude of sea surface salinity (SSS) seasonal oscillations significantly [4]. In the research area closer to the Crimea coast the increase in the contribution of interannual variations in the total variability of SST field is marked [4]. 
Summary of results of contact hydrological measurements on ChersonesosBosporus section for 2007 - 2013 revealed the temperature increase in the cold intermediate layer (CIL). It is in agreement with the general warming of the Black Sea upper layers and is supported by distributions of the SST interannual anomalies based on the satellite data [6-8].

Thus, the summary of the results of previous research shows that the works in the $81^{\text {st }}$ cruise of $\mathrm{R} / \mathrm{V}$ Professor Vodyanitsky were carried out in an area with quite complex on a seasonal scale hydrological conditions that were under the impact of the synoptic and interannual variations.

The present article presents the results of the hydrological research carried out in November, 2015 nearby the Crimea coast and in the northwestern part of the Black Sea Western cyclonic gyre. The actual distribution of thermohaline characteristics in the survey period were compared with the climatic fields according to the dataset of hydrological and satellite measurements. The data of instrumental measurements of currents carried in the cruise quasisynchronously with the hydrological observations were applied for the interpretation of the observed features of the waters thermohaline structure.

Materials and methods. The locating scheme and numbers of the stations of the $81^{\text {st }}$ cruise of R/V Professor Vodyanitsky are shown in Fig. 1, $a$. At each station from the surface to the bottom applying Sea-Bird 911 plus CTD the sea water temperature and salinity were measured. All stations in the top $200 \mathrm{~m}$ of the three components of the velocity of currents were measured in all the stations located in the upper 200 m layer using Acoustic Doppler Current Profiler (ADCP).

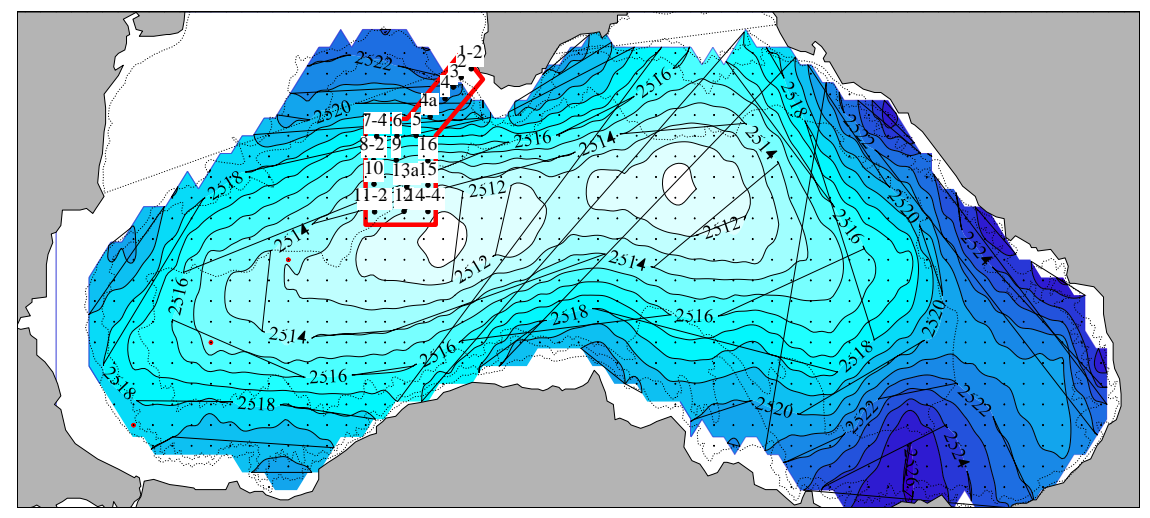

Fig. 1. Climate dynamic topography (0/300) for November (Work area is colored in red, black dots show the position of the hydrological stations) $-a$; dynamic topography $(0 / 300)$ and vectors of the geostrophic currents on the surface during the survey of November $3-10,2015-b$; geostrophic velocities $(\mathrm{cm} / \mathrm{s})$ during the survey normally to the Chersonesos-Bosporus section coming through the statins $3,4,4 a, 5,9,10-c$ 
To interpret the water structure features obtained during the expedition, the climate hydrological conditions in the research area were analyzed and their levels of the synoptic, seasonal and interannual variability were estimated. For that purpose the data of the array of MHI Oceanographic Data Bank [9] climatic hydrological measurements and the array of MyOcean Pathfinder V5.2 (PFV52) AVHRR satellite measurements with high spatial and temporal resolution, containing the daily SST averages in the nods of $0,04 \times 0,04^{\circ}$ regular grid from January 1982 to January 2016 were applied [10]. According to [11], the temporal period over 30 years is sufficient to obtain statistically significant climate norms and to estimate interannual variability trends. The daily averaging permits to assess the level of synoptic variability.

In accordance with the satellite data [10] the synoptic, seasonal and interannual root mean square deviations (RMSD) of SST were calculated in each grid node for the entire Black Sea. Synoptic SST RMSD was calculated on the mean daily SST series for each month of each year and then was averaged for all 397 months (RMSD ${ }_{\text {syn }}$ ). To calculate the seasonal RMSD on the average daily SST values the time series of its mean monthly values were obtained. They were applied to calculate SST RMSD for each year and then in their turn were averaged for 33 years $\left(\mathrm{RMSD}_{\text {seas }}\right)$. The interannual RMSD were calculated for the time series of 33 monthly SST values for January, February, etc. and then averaged for all 12 months (RMSD interann $_{\text {) }}$.

To determine the phase of the SST low-frequency variability the period of the expeditionary measurements falls within based on the data of [10] the anomalies of mean monthly SST as the difference between the SST values for a specific month each year and its mean climatic values for that month were calculated.

Interpretation of the thermohaline water structure actual features was carried out involving the daily satellite maps of SST for the entire Black Sea, the instrumental measurements of currents and results of geostrophic calculations according to the survey, as well as the distributions of the vectors of model geostrophic currents [12] during the survey.

Principal results. Water circulation in the research area in November 2015. The results of geostrophic calculations (Fig. 1, b, c) and instrumental measurements of currents (Fig. 2) show that an intense current of the north-western direction was monitored over the continental slope on the Chersonesos-Bosporus section. This current can be considered as the coastal branch of the Black Sea Rim Current. According to the geostrophic calculations, this branch was observed in 0 $150 \mathrm{~m}$ layer with a maximum speed $(30 \mathrm{~cm} / \mathrm{c})$ at the surface (Fig. 1). According to the data of instrumental measurements, the highest velocity of the Rim Current coastal branch was monitored in the upper $50 \mathrm{~m}$ layer. Maximum value of the full velocity vector at $7 \mathrm{~m}$ horizon reached $58 \mathrm{~cm} / \mathrm{s}$ (Fig. 2, a). The maximum of zonal velocity component was $20 \mathrm{~cm} / \mathrm{s}$ (Fig. $2, g$ ), the one of the meridional velocity component $-50 \mathrm{~cm} / \mathrm{s}$ (Fig. 2, h). The intensity of the Rim Current coastal branch weakened as the depth increased. At $150 \mathrm{~m}$ horizon the velocity vector value decreased to $12.5 \mathrm{~cm} / \mathrm{s}$ (Fig. 2, f). 


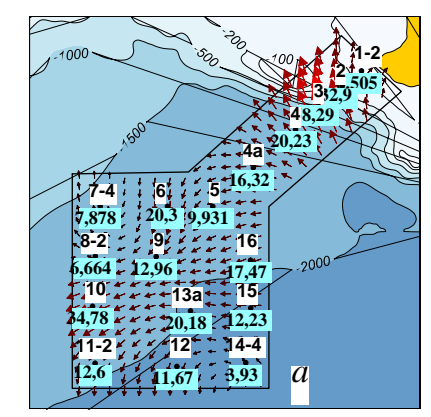

Fig. 2. Vectors of currents at the horizons of $7 \mathrm{~m}(a), 25 \mathrm{~m}(b), 60 \mathrm{~m}(c), 100 \mathrm{~m}(d), 150 \mathrm{~m}(e)$, distributions of the zonal $(f)$ and meridional $(g)$ component of the velocity of currents on the Chersonesos-Bosporus section based on the data of instrumental measurements

The south-eastern undersurface countercurrent was observed over the coastal shelf of the Chersonesos-Bosporus section northern edge. This current was wellmonitored at $75 \mathrm{~m}$ horizon, where the full velocity vector value was $28 \mathrm{~cm} / \mathrm{s}$ (Fig. 2, d). The countercurrent core was found between 70 and $80 \mathrm{~m}$ horizons with the zonal velocity component maximum of $\sim 15 \mathrm{~cm} / \mathrm{s}$ and the meridional one of $25 \mathrm{~cm} / \mathrm{s}$ (Fig. 2, g, h).

In the central part of the basic polygon the strengthening of the south-western currents was observed. It can be interpreted as the Rim Current southern branch manifestation (Fig. 1, b, $c$; 2). On the Chersonesos-Bosporus section, going through the basic polygon, the maximum of instrumentally measured velocity zonal component of the Rim Current southern branch $(35 \mathrm{~cm} / \mathrm{s})$ was observed at depths 
of $10-30 \mathrm{~m}$, the meridional one $(15 \mathrm{~cm} / \mathrm{s})$ - at a depth of $70 \mathrm{~m}$ (Fig. 2, $g, h)$. In accordance with the geostrophic calculations, the Rim Current southern branch was weak and the velocities of the normal to the section did not exceed $6 \mathrm{~cm} / \mathrm{s}$ (Fig. 1, c).

Instrumental measurements of currents showed significant spatial variability of the Rim Current southern branch, depending on the depth (Figure 2, $a-g$ ). In the upper $7-75 \mathrm{~m}$ layer this branch intersected the central part of the polygon, following in a south-western direction. The maximum velocity was observed actually near the southwestern boundary of the polygon. At the upper horizon of the measurements $(7 \mathrm{~m})$, the maximum of the velocity vector was about $35 \mathrm{~cm} / \mathrm{s}$. At $25 \mathrm{~m}$ horizon the velocity increased to $41 \mathrm{~cm} / \mathrm{s}$ and at depths of 50 and $75 \mathrm{~m}$ it weakened again to 33 and $25 \mathrm{~cm} / \mathrm{s}$, respectively. At $100 \mathrm{~m}$ horizon with a further weakening of the velocity bifurcation of the Rim Current southern branch was observed. One part of the current moved westward in the zonal direction, another one was still directed to the southwest. The maxima of the velocity vectors in the both branches reached $15 \mathrm{~cm} / \mathrm{s}$ (Fig. 2, e). At $125 \mathrm{~m}$ horizon the Rim Current bimodal pattern maintained, but the velocity of the both branches weakened and did not exceed $8-8.5 \mathrm{~cm} / \mathrm{s}$. At the $150 \mathrm{~m}$ horizon the Rim Current south branch was quasizonal current of the western direction. At the same time there was a slight increase in its intensity observed. Maximum velocity (up to $10 \mathrm{~cm} / \mathrm{s}$ ) was found by the western boundary of the polygon (Fig. 2, f).

Except the Black Sea Rim Current branches, in accordance with the data of instrumental measurements the other elements of circulation can be found within the polygon area. In the north-west of the polygon the anticyclonic meander was observed. It was well defined in the upper $7-25 \mathrm{~m}$ layer and at $100 \mathrm{~m}$ horizon in the form of a closed gyre (Fig. 2, $a, b, d$ ). In the south-eastern part of the polygon the cyclonic meander was found in $7-75 \mathrm{~m}$ layer (Fig. 2, $a-c$ ). The weak current (up to $5 \mathrm{~cm} / \mathrm{c}$ ) of the eastern direction was observed near the northern polygon boundary in the area of the station 5 (Fig. 2, $c, g$ ).

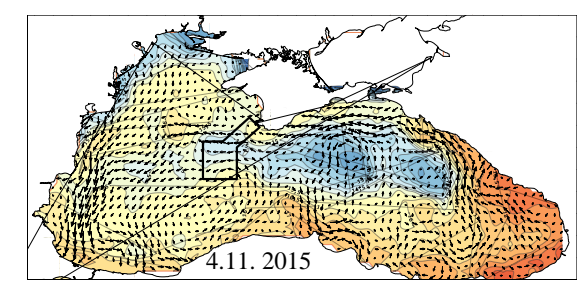

Fig. 3. Vectors of the model currents against the mean daily SST distributions $\left({ }^{\circ} \mathrm{C}\right)$ based on the satellite data within the period of November 4 - 7, 2015 
Instrumental measurements of currents carried out during the cruise in the surface layer are generally in good agreement with the model currents [12] shown in Fig. 3. The only difference is that in the distribution of the vectors of the model currents the Rim Current coastal branch above the continental slope is less clear.

Structure of the thermohaline fields in November, 2015. The main structural features of the thermohaline fields in the upper active layer were clearly manifested in the vertical distribution of temperature, salinity and density at all stations of the polygon and on the Chersonesos-Bosporus section (Fig. 4).

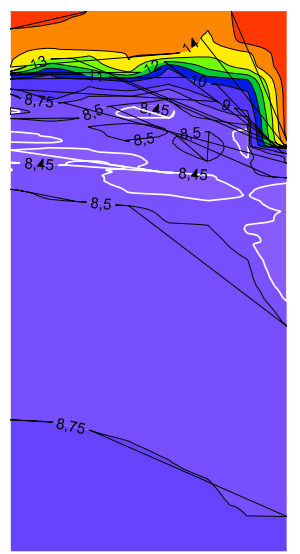

Fig. 4. Vertical distributions of temperature $\left({ }^{\circ} \mathrm{C}\right)(a)$, salinity $(\%)(b)$ and density (cond. units) $(c)$ on the Chersonesos-Bosporus section and distributions of temperature $(d)$ and salinity $(e)$ in the survey area at $1 \mathrm{~m}$ horizon for November $3-10,2015$

The upper quasi-homogeneous layer (UQL) at the majority of stations had thickness of $\sim 20-30 \mathrm{~m}$. At the coastal shelf it was deeper up to $75 \mathrm{~m}$ (Fig. 4, $a-c$ ). At some stations two-step UQL structure was monitored, while the water temperature in upper step was $1-1.5{ }^{\circ} \mathrm{C}$ higher than in the lower one. The 
appearance of such step is due to the change of the synoptic conditions in the research area.

Giving the characteristic of the horizontal structure of the temperature field within the UQL (Fig. 4, d), it should be noted that the warmest waters were found in shallow coastal shelf off the coast of the Crimea $\left(15.8^{\circ} \mathrm{C}\right)$ and in the southeastern part of the research area $\left(15.65^{\circ} \mathrm{C}\right)$. The temperature minimum was observed in the north-western part of the basic polygon $\left(13.19^{\circ} \mathrm{C}\right)$.

The analysis of satellite data and vectors of model currents permitted to explain the features of the actual UQL temperature distribution. Fig. 5 shows that period of the survey in the seasonal cycle of SST in 2015 fell on the period of surface waters cooling, which was the most intense in the first half of October. According to the configuration of $16{ }^{\circ} \mathrm{C}$ isotherm, in the latitudinal band 43.6 $43.9^{\circ} \mathrm{E}$, crossing the central part of the research area, the cooling was more rapid than in its northern and southern part (Fig. 5). Analysis of the maps of the vectors of currents for the entire Black Sea showed that this feature of the SST seasonal variability is largely associated with water circulation. During the survey the coldest waters were located in the eastern part of the sea, close to the center of East cyclonic gyre (ECG). At the same time there were two separate areas of minimum water temperature (the western one - between 35 and $36.5^{\circ} \mathrm{E}$, and the eastern between 37 and $38.5^{\circ} \mathrm{E}$ ) observed within the ECG. These areas coincide with the position of the two local cyclonic gyres, which are well defined on the maps of model surface currents (Fig. 3). "Tongue" of the relatively cold waters from the western area spread along the Rim Current and crossed the central part of the research area, which is in good agreement with the distribution of the actual temperature in the survey period.

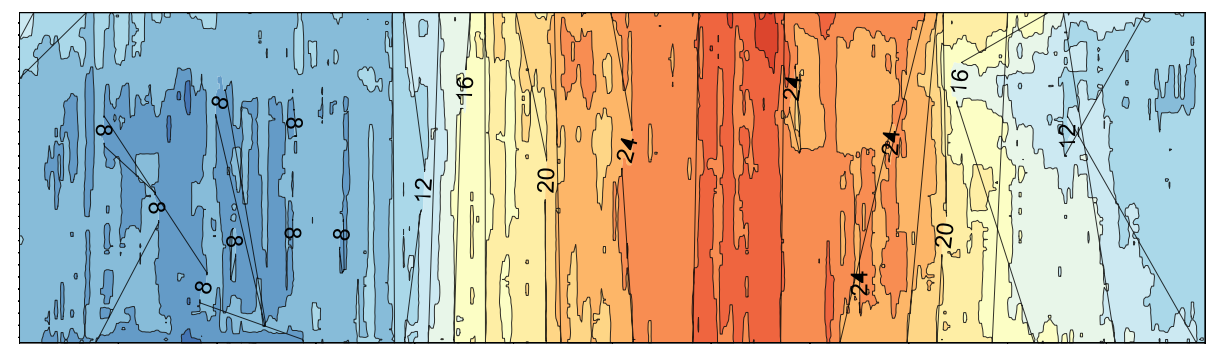

Fig. 5. Intraannual cycle of temperature $\left({ }^{\circ} \mathrm{C}\right)$ in 2015 according to the mean daily satellite on the Chersonesos-Bosporus section. Hatching marks the period and area of the expeditionary survey

The higher UQL temperature in the northern and southern parts of the research area can also be explained by water advection by surface currents. In shallow water, warm water comes along the northern periphery of the Rim Current, which is confirmed by satellite maps SST and distribution of the vectors of model currents (Fig. 3). In the southern part of the polygon the warm waters penetrated along the eastern periphery of the cyclonic gyre located in the western part of the sea close to the Anatolian coast (Fig. 3).

PHYSICAL OCEANOGRAPHY NO. 4 (2016) 
Horizontal distribution of salinity within the UQL (Fig. 4, e) was qualitatively consistent with its climatic distribution, according to which there was an increase in salinity in the southern direction closer to the ECG center. Most freshened waters $(18.08 \%$ o) were located in the coastal shelf zone off the Crimea coast, the most salt ones $(18.37-18.44 \%$ ) - in the deep eastern and southern parts of the polygon. A the same time the area of high salinity waters stretched in a form of "tongue" along the Rim Current southern branch, which is clearly seen from the distribution of vectors of instrumentally measured currents (Fig. 2, $a, b$ ).

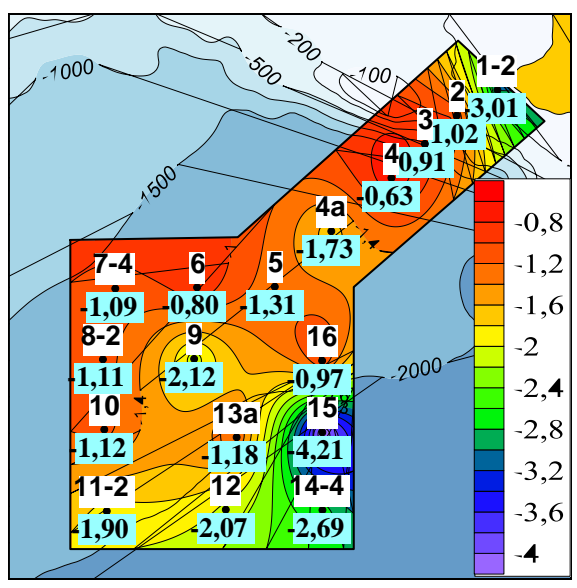

Fig. 6. Distributions of the values of maximum vertical temperature gradient $\left({ }^{\circ} \mathrm{C} / 1 \mathrm{~m}\right)(a)$ and its location depth $(\mathrm{m})(b)$, temperature in the CIL core $\left({ }^{\circ} \mathrm{C}\right)(c)$ and its location depth $(\mathrm{m})(d)$ in the period of survey. The panel in Fig. 6, $d$-graph of linear connection between temperature in the CIL core (ordinates axis) and its location depth (abscissa axis), hatched lines are the boundaries of $95 \%$ confidence interval

The water circulation features also reflected in the distribution of the characteristics of the transition layer. Higher values (in absolute value) of the vertical temperature gradient (up to $4.21^{\circ} \mathrm{C} / 1 \mathrm{~m}$ ) were observed in the southeast of the basic polygon, i. e. in the southern periphery of the Rim Current southern branch closer to the ECG center (Fig. 6, a). Here, the depths of the transition layer 
were relatively small, about $25-28 \mathrm{~m}$ (Fig. 6, b). In the northern direction the values of temperature gradients in the transition layer decreased, and its layer depth increased, reaching $0.8^{\circ} \mathrm{C} / 1 \mathrm{~m}$ and $42 \mathrm{~m}$ respectively at the station 6 at the northern boundary of the polygon. Local rise of the transition layer to a depth of 27 meters was observed in the area of station 4a in the divergence zone of the Rim Current southern and coastal branches (Fig. 2, b). At the same time the temperature gradient value increased to $1.73^{\circ} \mathrm{C} / 1 \mathrm{~m}$. Closer to the continental slope and shelf, where the Rim Current coastal branch came across, the depth of both the transition layer and UQL increased from north to south by $36 \mathrm{~m}$ at the station 4 to $76 \mathrm{~m}$ at the station 1-2. At the same time, in contrast to the coverage of the Rim Current southern branch, the gradient values here increased in the northern direction (Fig. 6, $a, b)$. The highest gradient values $\left(3.01^{\circ} \mathrm{C} / 1 \mathrm{~m}\right)$ were marked at the station $1-2$, where according to the instrumental measurements the countercurrent of the southeastern direction was observed (Fig. 2, $d, g, h$ ). Intensification of the temperature gradients on the coastal shelf of could be caused by the interaction of the Black Sea Rim Current southern branch and the coastal countercurrent.

There was a cold intermediate layer (CIL) lower the transition one. Its core temperature values slightly changed $\left(8.39-8.45^{\circ} \mathrm{C}\right)($ Fig. $6, c)$. At the same time the location depth of the CIL core changed in the wide range: from $46 \mathrm{~m}$ on the periphery of the Black Sea Rim Current southern branch in the south-eastern part of the polygon to $121 \mathrm{~m}$ above the continental slope (Fig. 6, $d$ ). In general, the spatial distribution of the CIL core depth was of a rather complicated character. This is due to the fact that the CIL had an inhomogeneous vertical structure, and there were only two, sometimes three, temperature minima observed at the majority of the stations. For example, there was a break of the CIL observed on the Chersonesos-Bosporus section crossing the basic polygon, between the station $4 \mathrm{a}$ and 5. At the same time the upper layer of minimum temperature water was found in a layer of $50-60 \mathrm{~m}$, the lower one - in a layer of $75-100 \mathrm{~m}$ (Fig. 4, a). This effect could be caused by the current with the eastern velocity component, which was observed according to the instrumental measurements at the depth of $60 \mathrm{~m}$ (Fig. 2, c, g). Similar CIL breaks were monitored at the stations 2 and 3 (Fig. 4, a), where there was the impact of the coastal countercurrent (Fig. 2, $d, g, h$ ).

In the distribution of the CIL features it is possible to note a tendency of the temperature growth in the CIL core while increasing its location depth. Between these parameters the significant direct linear correlation with the value $R \sim 0.58$ was found (Fig. 6, $d$, panel). The increase of temperature values in the CIL during its deepening can be explained by the more intense vertical mixing compared with the overlying stratified layers.

There was a tendency to a decrease in temperature and salinity under the CIL in the layer $100-200 \mathrm{~m}$ from north to south as a result of the general deepening of the main thermocline and halocline in the northern direction. At $100 \mathrm{~m}$ horizon in the southern part of the polygon the water temperature reached $8.57^{\circ} \mathrm{C}$, the salinity $-20.9 \%$. Above the continental slope the temperature dropped to $8.43-8.44{ }^{\circ} \mathrm{C}$, the salinity - to $19.67 \%$. The most freshened water (19.04 \%o) was located in the coastal shelf zone off the Crimea coast (Fig. 7). The distributions of temperature and salinity below $200 \mathrm{~m}$ were generally consistent with the structure of water in 
deep layers of the Black Sea [1], and the actual values of thermohaline parameters were close to climate norm.

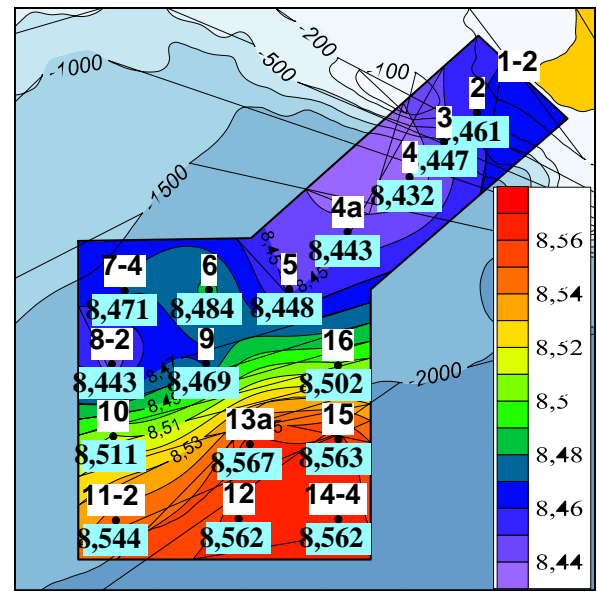

Fig. 7. Temperature $\left({ }^{\circ} \mathrm{C}\right)(a)$ and salinity (\%o) distributions $(b)$ at $100 \mathrm{~m}$ horizon for November, 3 10, 2015

Anomalies of thermohaline fields in November, 2015. Distributions of the anomalies of actual temperature values in the survey period relatively to their mean monthly climate values according to [9] showed that the entire research area the temperature in the surface layer was above norm. Maximum anomalies were observed in the coastal shelf (up to $2.75{ }^{\circ} \mathrm{C}$ ) and in the south-eastern part of the basic polygon $\left(2.6-2.7^{\circ} \mathrm{C}\right.$ ) (Fig 8, a).

The salinity during the survey on the most of the research area was above norm. Only on the shelf, unlike the temperature, the weak negative salinity anomalies were observed (up to $0.03 \%$ ). The highest positive SSS anomalies $(0.11-0.13 \%$ ) were monitored in the eastern part of the polygon (Fig. 8, b).

A comparison of the CIL characteristics with the mean climate norm showed that the temperature in the CIL core within the entire research area was higher than the climate one, the maximum anomalies (up to $0.85^{\circ} \mathrm{C}$ ) were observed in the east of the polygon (Fig. 8, c). The CIL core was located $22-26$ m deeper than the climate norm in the area of the continental slope, central and southern parts of the polygon. It should be noted that in the area of the station $4 \mathrm{a}$ on the ChersonesosBosporus section the CIL core was located $28 \mathrm{~m}$ closer to the surface (Fig. 8, $d$ ). The rise of both the CIL and the transition layer in this area can be explained by the divergence of the two branches of the Rim Current, observed in the survey period. 


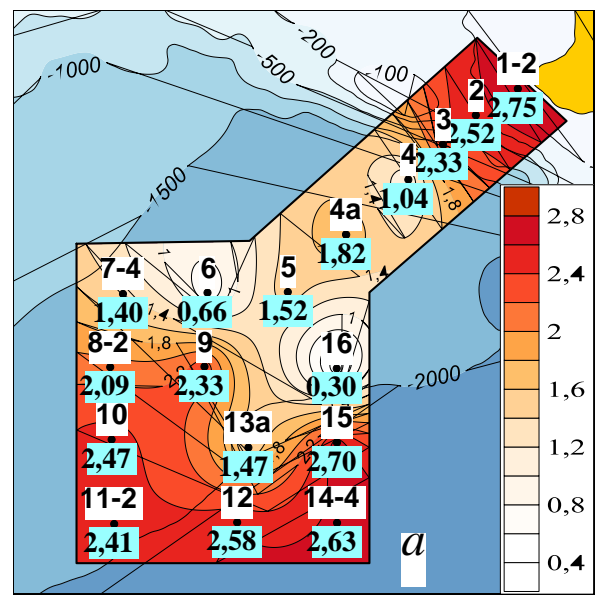

Fig. 8. Distributions of the anomalies: the temperature ones $\left({ }^{\circ} \mathrm{C}\right)(a)$ and salinity $(\%)(b)$ at $1 \mathrm{~m}$ horizon in the CIL core $\left({ }^{\circ} \mathrm{C}\right)(c)$ and its location depth $(\mathrm{m})(d)$ obtained according to the survey data relatively to the climate norms

The observed differences of the thermohaline water structure during the survey period in November 2015 from the climate norms, obtained according to the hydrological data, may be a manifestation of a synoptic and interannual variability. Distributions of synoptic, seasonal and interannual SST RMSD based on the satellite data along the Chersonesos-Bosporus section (Fig. 9, a) showed that within the survey period an appreciable redistribution of different variability types is observed. Closer to the Crimea coast the observed increase in the interannual SST variability under a sharp decrease of the seasonal and synoptic variability level is monitored. Under general increase of the SST synoptic variability level in the southern direction around $44^{\circ} \mathrm{N}$ its local maximum, which coincides with the climate position of the Rim Current midstream, is checked [3, 7]. Thus, to the north from the climatic position of the Rim Current midstream levels of seasonal and synoptic variability decrease. In the Rim Current midstream itself the local increase of the synoptic and interannual variability is marked. To the south from the 
midstream in the central part of the WCG the interannual variability reduces and the seasonal one increases. Distribution of the SST anomalies in the survey period with respect to the hydrological climate showed that in the northern part of the Chersonesos-Bosporus section large values of positive anomalies are observed in the region of maximum interannual variations. In the southern part of the research area on the section high positive SST anomalies are observed in the area of the increase of synoptic variability and decrease of the interannual one.

Time series of the mean monthly interannual SST anomalies over the entire period of measurements at two points on the Chersonesos-Bosporus section (Fig. 9, b) and their linear trends showed general tendency of SST increase on long-term scale. Recently distribution of the SST anomalies along the entire section (Fig. 9, c) revealed that in the northern part of the section in November 2015, there were high positive SST anomalies $\left(\sim 1-1.5^{\circ} \mathrm{C}\right)$ observed. Thus, the positive anomalies of actual SST relative to the climatic norm) in the northern part of the Chersonesos-Bosporus section are in good agreement with long-term trends of the SST variability, detected according to the satellite data.

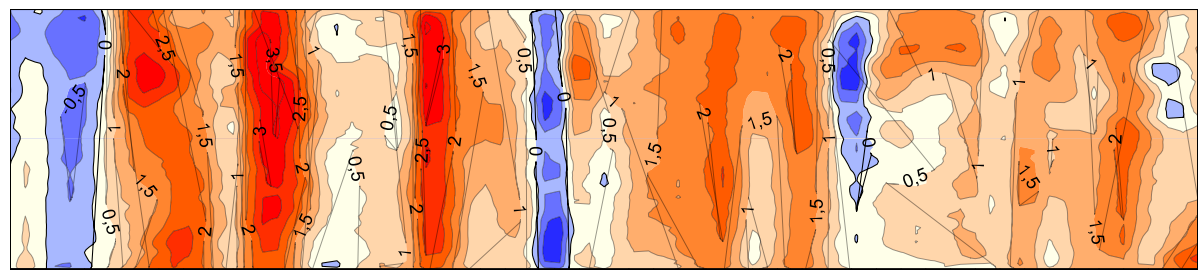

Fig. 9. Distributions of the interannual (solid line), seasonal (dashed curve) and synoptic (dotted line) SST RMSD values $\left({ }^{\circ} \mathrm{C}\right)$ on the Chersonesos-Bosporus section $(a)$; mean monthly interannual SST anomalies in the section points with coordinates $44.3^{\circ} \mathrm{N}$ (solid curve) and $43.8^{\circ} \mathrm{N}$ (dotted line) and their linear trends $(b)$; interannual SST anomalies along the entire Chersonesos-Bosporus section (c) based on the satellite data. The expeditionary survey period and area are marked by hatching

In the central part of the research area the weak negative interannual SST anomalies (up to $0.5^{\circ} \mathrm{C}$ ) were observed and in the south - the positive ones (up to $1{ }^{\circ} \mathrm{C}$ ) again. Taking into consideration the increase of the SST synoptic variability level, obtained from satellite data southward of $44{ }^{\circ} \mathrm{N}$ (Fig. 9, a), it can be assumed that during the survey period higher SST values as compared with climate norm are in a greater degree due to the synoptic variability. 
It should be noted that the synoptic processes are most clearly manifested in the sea surface layer and considerably attenuate with depth. The CIL characteristics show that the temperature field variability in the subsurface layer is more in line with the low-frequency SST variability. The positive temperature anomalies in the CIL core in November 2015 with respect to the climate norm reflect the general tendency of SST increase on long-term scale. In addition to a positive linear SST trend, the abnormally warm winters were recently observed in the research area. For example, in accordance with the satellite data, in December 2012, 2013 and 2014 positive interannual SST anomalies reached 3, 1.5 and $1.5{ }^{\circ} \mathrm{C}$, respectively (Fig. 9, c). Such high positive SST anomalies in the winter contributed to the increase of the CIL thermal content in November 2015.

Conclusions. The analysis of the survey results during the $81^{\text {st }}$ cruise of $\mathrm{R} / \mathrm{V}$ «Professor Vodyanitsky» showed that that the dynamic processes and thermohaline fields in November 2015 were in good agreement with the climatic water structure nearby the Crimea coast and in the northwestern part of the Black Sea Western cyclonic gyre. Also, the impact of interannual and synoptic variability formed the variations of hydrological fields from the climate norm.

The Black Sea Rim Current was represented by the two branches. The more intense one, the Rim Current coastal branch of northwestern direction, was observed over the continental slope. Another branch of the Rim Current, the southern one, came southwestward across the central part of the basic polygon. The subsurface southeastern countercurrent was monitored over the coastal shelf. In the southeastern part of the basic polygon the cyclonic meander was discovered.

The upper quasi-homogeneous layer had thickness of $\sim 20-30 \mathrm{~m}$. At the coastal shelf it was deeper up to $75 \mathrm{~m}$. The temperature was above climate norm in the surface layer within the entire research area. Maximum anomalies were observed in the coastal shelf (up to $2.75{ }^{\circ} \mathrm{C}$ ) and in the south-eastern part of the basic polygon $\left(2.6-2.7^{\circ} \mathrm{C}\right)$. The salinity during the survey on the most of the research area was above normal. Only on the shelf, unlike the temperature, the weak negative salinity anomalies were observed (up to $0.03 \%$ ).

The temperature in the CIL core within the entire research area was higher than the climate one, the maximum anomalies (up to $0.85^{\circ} \mathrm{C}$ ) were observed in the east of the polygon. The CIL core was located $22-26 \mathrm{~m}$ deeper than the climate norm in the area of the continental slope, central and southern parts of the polygon. In the central part of the Chersonesos-Bosporus section the CIL core was located $28 \mathrm{~m}$ closer to the surface that can be explained by the divergence of the two branches of the Rim Current.

The observed differences of the thermohaline water structure during the survey period in November 2015 from the climate norm, obtained according to the hydrological data, may be a manifestation of a synoptic and interannual variability. High positive anomalies of actual SST temperature relatively to the hydrological climate are observed nearby the Crimea coast in the area of maximum interannual variations. In the southern part of the research area the positive anomalies of actual SST temperature were monitored in the synoptic variability increase area and the interannual variability decrease area, respectively. 
The higher temperature in the CIL core in November, 2015 relatively to the climate norm are in good agreement with general tendency of sea surface temperature growth on the multi-year scale. Abnormally warm winters in the research area in the recent years have contributed to the CIL thermal content increase.

\section{REFERENCES}

1. Ivanov, V.A., Belokopytov, V.N., 2011, “Okeanografiya Chernogo morya [The Black Sea Oceanography]”, Sevastopol, ECOSI-Gidrofizika, 209 p. (in Russian).

2. Artamonov, Yu.V., Belokopytov, V.N. \& Babiy, M.V. [et al.], 2008, “Osobennosti sezonnoy izmenchivosti temperatury poverkhnosti i tsirkulyatsii vod Chernogo morya [Features of the Black Sea surface temperature variability and water circulation]", Osnovnye rezul'taty kompleksnykh issledovaniy v Azovo-Chernomorskom basseyne i Mirovom okeane. Yubileynyy vypusk, pp. 102-109 (in Russian).

3. Artamonov, Yu.V., Belokopytov, V.N. \& Skripaleva, E.A., 2012, “Osobennosti izmenchivosti gidrologicheskikh i bioopticheskikh kharakteristik na poverkhnosti Chernogo morya po dannym sputnikovykh i kontaktnykh izmereniy [Variability features of the hydrological and biooptical characteristics in accordance with the satellite and contact measurements]", Ustoychivost' i evolyutsiya okeanologicheskikh kharakteristik ekosistemy Chernogo morya, Pod red. V.N. Eremeeva, S.K. Konovalova, Sevastopol, ECOSI-Gidrofizika, pp. 88-115 (in Russian).

4. Artamonov, Yu.V., Babiy, M.V. \& Skripaleva, E.A., 2005, "Regional'nye osobennosti mezhgodovoy izmenchivosti polya temperatury na poverkhnosti Chernogo morya [Regional features of the interannual variability of the surface temperature field]”, Sistemy kontrolya okruzhayushchey sredy, pp. 240-242 (in Russian).

5. Ginzburg, A.I., Kostianoy, A.G. \& Sheremet, N.A., 2001, “Ob ispol'zovanii sputnikovykh dannykh $v$ issledovanii sezonnoy $i$ mezhgodovoy izmenchivosti temperatury poverkhnosti Chernogo morya [On satellite data application and seasonal and intra-annual variability of the Black Sea surface temperature]”, Issledovanie Zemli iz kosmosa, no. 1, pp. 51-61 (in Russian).

6. Ginzburg, A.I., Kostianoy, A.G. \& Sheremet, N.A., 2008, "Sea surface temperature variability”, The Black Sea Environment, Part Q, Berlin, Heidelberg, Springer-Verlag, no. 5, pp. 255-276, doi: 10.1007/698_5_090.

7. 2014, "Issledovanie osobennostey gidrologicheskoy struktury vod Chernogo morya v Sevastopol'skom regione i prilegayushchikh akvatoriyakh po dannym sinopticheskikh s"emok Morskogo gidrofizicheskogo instituta v 2007-2013 gg. [Research of the Black Sea hydrological water structure features in the Sevastopol region and adjacent water areas in accordance with Marine Hydrophysical Institute synoptic surveys in 2007-2013]”, Otchet po grantu RFFI No. 14-45-01639, 44 p. (in Russian).

8. Artamonov, Yu.V., Deryushkin, D.V. \& Kiryushchenko, I.G. [et al.], 2012, “Issledovaniya gidrologicheskoy struktury vod v severnoy chasti Chernogo morya v avguste 2011 g. (po materialam 69-go reysa NIS «Professor Vodyanitskiy») [Hydrophysical water structure research in the Black Sea northern part in August 2011 (according to the data acquired in the $69^{\text {th }}$ Cruise of R/V Professor Vodyanitsky)], Geologo-okeanologicheskie issledovaniya kontinental'noy okrainy Kryma i prilegayushchey kotloviny Chernogo morya, Kiev, OMGOR, pp. 87-104 (in Russian).

9. Andryushchenko, E.G., Galkovskaya, L.K. \& Godin, E.A. [et al.], 2010, “Bank okeanograficheskikh dannykh MGI NAN Ukrainy: informatsionnye resursy i dostup k dannym [Bank of oceanographic data of Marine Hydrophysical Institute NAS of Ukraine: information resources and data access]”, Sevastopol, ECOSI-Gidrofizika, 59 p., http://ocean.nodc.org.ua (access date 16.08.2013).

10. http://www.myocean.eu/interactive catalogue/sst_bs (access date 01.02.2016).

11. Monin, A.S., 1999, “Gidrodinamika atmosfery okeana i zemnykh nedr [Hydrodynamics of the Ocean atmosphere and entrails of the Earth]", Saint Petersburg, Gidrometeoizdat, 524 p. (in Russian).

12. http://dvs.net.ru/mp/data/main_ru.shtml (access date 02.03.2016). 